DOI: 10.1515/ausp-2015-0015

\title{
Reflections on the Status of Hungarian Loanwords in Old Romanian Translations
}

\author{
Enikő PÁL \\ Department of Humanities \\ Sapientia Hungarian University of Transylvania (Miercurea Ciuc, Romania) \\ enikopaldr@gmail.com
}

\begin{abstract}
Translation has always been important for religion as a way of preaching God's word. The first Romanian translations of religious texts, including the first (although incomplete) translation of the Bible, date from the sixteenth century. In this early period of Romanian writing, Romanian translators encountered several problems in conveying the meaning of these texts of a great complexity. Some of the difficulties were due to the source texts available in the epoch, others to the ideal of literal translation, to the principle of legitimacy or to the relatively poor development of Romanian language which limited the translators' options. The present study focuses on the causes and purposes for which lexical items of Hungarian origin interweave old Romanian translations. In this epoch, Hungarian influence was favoured by a complex of political, legal, administrative and sociocultural factors, sometimes even forced by these circumstances. On the one hand, given the premises of vivid contacts between Romanians and Hungarians in the regions where the old Romanian translations (or their originals) can be located, a number of Hungarian loanwords of folk origin penetrated these texts. On the other hand, when using Hungarian sources, translators have imported useful source language calques and loanwords, which have enriched Romanian language.
\end{abstract}

Keywords: folk, elitist, (Hungarian) loanwords, translation strategy

1. "Translations are facts of target cultures" (Toury 1995: 29) and, as such, dealing with old Romanian translations we shall start from the contextual reasons for what these are and do, relating certain features of the sociocultural context constraining them. First of all, we shall point out the fact that the first translations into Romanian language date from the sixteenth century and, as a matter of fact, these translations are also (one of) the first texts written in Romanian language, at least among those preserved until the present day. ${ }^{1}$ Therefore, these translations

1 Writing in Romanian naturally precedes the oldest Romanian translations since the need to convey a message of any kind other than spoken would certainly precede translation phenomena. 
provide us the first, relatively overall view on old Romanian language. Given the circumstance that Romanian writing itself had been in a somewhat precarious condition, the first translations in this vernacular language naturally confronted several problems due to certain disadvantages pertaining to the target language per se. On the other hand, and what is more important to translation phenomena, these translations are translations of religious texts, ${ }^{2}$ which once again determined the nature of translation into Romanian in the old period. Hence, these translations reflect some common features that characterise all Bible translations, but, apart from that, they also have certain particular characteristics.

In the case of old Romanian biblical translations we might speak of individual rather than collective translational norms, models and behaviour, since they may be regarded as "isolated practices which do not pertain to a unitary activity" (Gafton 2009: 1). There existed a general principle which governed the process of rendering holy books, i.e. literal translation. However, in the case of old Romanian translations, unlike Bible translations in other vernacular languages, the ideal of literal translation, apart from continuing a tradition meant to legitimate the target text for the Church and for the readers, was also determined by the relatively poor condition of old Romanian language. On the one hand, the translators' main concern was not to alter God's words, thus showing less regard for the requirements of the target language or for the readers. On the other hand, they sometimes apply word for word translation partially because Romanian language lacked in means of expression appropriate for the translation of the biblical texts (Rosetti 1931: 138).

Although a well-defined translation theory did not exist in the sixteenth century yet, certain direct or indirect traces regarding the translators' conception of translation phenomena may be found in either their testimony expressed in the Preface of a translation, or in their concrete translation solutions they adopted (see also Gafton 2011a: 205-207; Gafton 2011b: 261-272). For instance, the process of source selection was also an issue of legitimacy for Romanian translators, as in the sixteenth century the Romanian translators' choice for one source over another was guided by several factors. Adopting a model for Bible translation available at the time (Slavonic, Latin, Hungarian, German) was determined, on a restricted level, by the local authority, represented by the dominant confession (orthodox or protestant), and, on a larger level, by the

On the other hand, these translations dating back to the sixteenth century are, in turn, copies of older originals, which show that a certain translation tradition and, previously, writing in Romanian must have existed prior to this century as well, only those writings have perished.

2 The texts we shall refer to in the present study are: fragments of the Acts of the Apostles, of Gospel and of Apostolic Letters: CV, Св, СP, CS; books of psalms: FRAG. TOD.; homilies: $\mathrm{CC}_{1}, \mathrm{CC}_{2}$; a prayer book: мО; Bible translations: РО, тв, вв (for the abbreviations see References at the end of the paper). These belong to the sixteenth century except for the last two composed in the seventeenth century. 
cultural sphere of influence (Eastern, Greek-Slavonic in Moldavia and Wallachia vs. Western, Latin influence in Transylvania) to which the region where the translation had been carried out belonged to (Gafton 2009: 3). In this regard, we shall point out that many of the first Romanian translations were made in BanatHunedoara, where they appeared under the auspices of Calvinism, propagated first by Hungarians. Another important aspect to be taken into account is that, due to particular historical, political, cultural etc. conditions, in the region of Banat-Hunedoara, Hungarian language enjoyed a high prestige, which could confer authority to the Bible versions written in this vernacular language. In addition, in these regions there existed long term and vivid contacts between Romanians and Hungarians, thereby Hungarian language could have been even more accessible for Romanian translators than the acknowledged worship languages. As a consequence, translators of sacred texts frequently appeal, in different proportions, to Hungarian sources in Banat-Hunedoara.

In the present study we shall focus on the micro-level data (Lambert \& van Gorp 1985) included in old Romanian translations, insisting on the matter of word selection, in this case of those of Hungarian origin, the main goal being to describe the status of Hungarian loanwords in these texts. In this regard, their assessment is made based on whether these loanwords are simply translation solutions or, beyond that, they reflect a certain translation strategy.

2. Old Romanian translations record a considerable number of Hungarian loanwords, which represent the second most important lexical stratum of foreign origin in these texts, after the Slavonic elements. Naturally, their proportion also varies according to the source language of the translation. Romanian translations of Hungarian sources record the largest number of Hungarian loanwords for obvious reasons, but they are found in translations of Slavonic sources as well and with quite a frequency, which we believe not to be random. For the first case, it can be stated that "tolerance of interference (...) tends to increase when a translation is carried out from a 'major' or highly prestigious language / culture, especially if the target language / culture is 'minor', or 'weak' in any other sense" (Toury 1995: 278). As stated above, Hungarian language enjoyed prestige at the time, a high regard, which could have been provided also by the prior existence of a Bible version in this vernacular language, whereas Romanian "had a poor vocabulary and with no sufficient terms at hand to correspond to all the terms in the Slavonic or Hungarian versions of the Bible" (Rosetti 1931: 138).

Translation engages the translator in selection operations in order to respond to the requirements of the source meaning and to his own language system. During translation not only the target language interacts with the source language, but in turn, it operates within itself imposing selection from a wide range of possible correspondents. If the target language lacks an appropriate equivalent, translators 
may recourse to borrowing. Hence, translations of Hungarian sources ${ }^{3}$ recorded several Hungarian loanwords of bookish origin, which penetrated into Romanian language and through these translations some of them were preserved in the following centuries as well, eventually entering the spoken use too, at least in certain regions. On the other hand, translators also appealed to a priori linguistic data, i.e. Hungarian loanwords of folk origin, borrowed in previous epochs, which interweave old Romanian translations. In each case translation appears as a problem-solving event, but applying a direct or an oblique translation technique is not always determined by linguistic constraints only. In other words, the use of Hungarian loanwords in these translations does not always respond to a real necessity imposed by a need for equivalence (for examples see infra 3.4.4).

3. In a target-oriented approach, the target text is interpreted as a result of the constraints and influences of the target linguistic (and cultural) context, or as a cause for the introduction of changes into the target system. In this regard, Hungarian loanwords function to fill a conceptual gap, to express a nuance of an existing notion or, in other cases, to enrich or to refine the Romanian language system by enlarging its synonymic series in order for it to become an instrument of culture capable of rendering the biblical texts. The former two cases may reflect a linguistic necessity, while the latter one seems more like a strategy, especially in certain contexts, as we shall see in the following.

The translator as a target culture agent negotiates contextual constraints pertaining to the target culture in its historical, geographical, social and ideological coordinates. In this regard, Hungarian loanwords are fully justified, especially given the context of Romanian-Hungarian bilingualism in the region of Banat-Hunedoara, where the majority of the analysed Romanian translations belong to (exceptions being $\mathrm{CB}, \mathrm{CC}_{2}$, СР and certain texts from $\mathrm{Cs}$ ). In other words, in these translations, Hungarian loanwords - even if they do not reflect a necessity of the system - are neither futile nor peripheral since they are part of the regional norm, which not only accepts or tolerates Hungarian elements, but in which these are quite natural.

In order to determine whether Hungarian loanwords represent solely required elements of the translation, i.e. they solve a problem arising in the source text,

3 See Molitvenic [The Prayer Book] (1564), whose original is considered to be the Hungarian Agenda azaz Szentegyházi chelekedetec, Mellyeket követnek közönségesképpen a keresztényi Ministerec és Lelkipásztoroc [Agenda i.e. holy deeds of Church which are commonly pursued by Ministers and Pastors, my translation] (Drăganu 1921-1922: 267; Gheție 1982: 13-15; Gheție \& Mareş 1985: 267). Another Romanian translation which has Hungarian sources is Cartea de cîntece [The Book of Psalms] (1570-1573) (Gheție \& Mareş 1985: 114). Probably the most complex old Romanian translation is Palia de la Orăştie [The Old Testament from Orăştie] (1581-1582) which, beside a Latin edition of Vulgata, follows Heltai's Pentateuh, a Hungarian version of the Bible (see the demonstration of M. Roques, in the Preface of his edition Po 1925: III - LXIII). 
or, beyond that, they reflect a deliberate and assumed strategy, we shall continue with a few examples.

3.1. Hungarian loanwords of bookish origin do not need particular explanations since their use is quite evident. They solve an immediate problem either because Romanian language did not have a proper term to denote a notion encountered in the source text, or because, for some reason, the Hungarian word seemed more suitable. They co-occur with their etymons from the source text, being characteristic especially of Calvinist Romanian texts from Banat-Hunedoara. They have relatively few derivatives, inflections and compounds and their functionality is limited to only one sequence of the target text, namely in which they appear. This is the case of words such as: batăr 'at least, though'; gheman 'diamond'; jemblă 'white bread'; lepiniu 'pita, crumpet'; mereu '(of gold) authentic, pure'; rudă 'pole’; siriu 'tool', 'instrument', 'weapon'; a sucui ‘to accustom'; şinor 'string', 'snare', 'braid', ‘cord' (in Po); and nemzet 'nation'; uluită 'confession' (in FRAG. TOD.).

In a few cases the distinction between folk and elitist Hungarian loanwords is somewhat difficult to make since their co-occurrence with their etymons from the source text may only reinforce a term already in use. This might be the case of: $a$ aldovani 'to sacrifice (oneself), to offer (oneself)'; a aldui 'to bless'; berc 'grove', 'copse', 'thicket'; giolgiu 'shroud, fine cloth' (in Po). The first two have a common root which proved to be quite productive in Romanian, which may imply their folk origin and a spoken usage however restricted. The term berc 'grove' had been recorded in the previous century as well as subsequently, which may reflect its spoken use. As for giolgiu 'shroud', it has no other attestations from the sixteenth century but it has been noted in nowadays' speech. In these cases, inserting the Hungarian loanword might not represent a constraint due to the source text, or, in any case, not exclusively imposed by it, but perhaps the translator's decision, an option as natural as the choice for any other element of his active vocabulary as a bilingual speaker.

There are some cases in which the Hungarian etymon does not appear in the source text or it does but in another passage, different from the context in which the loanword is included in the target text. Here we could mention words such as: alnic 'cunning', 'sly', 'treacherous'; naşfă 'binding', 'ornament (of clothing)', 'jewellery’; a văndăgi 'to precipitate, to throw', 'to besiege' (in Po). The fact that these are used relatively independent of the source text, preceding or following their etymons, may be regarded as a clue for their folk status, not certainly though, since the translator's mind is able to retain, during translation, data which then can be employed independently of the source text. Thus, considering their isolated occurrences (recorded only in PO), we shall regard them as loanwords of bookish origin rather than otherwise. 
There are some other loanwords, which are used relatively independent of the source text too. This is the case of a adăvăsi 'to ravage, to perish' with a single occurrence in PO (Gen., 49/7), where it corresponds to Hung. el szelesztem 'to perish'. Similarly, pochiolat 'veil (to cover the head)' renders, in the passage in which it appears (Ex., 29/9), another Hungarian word: föketöket 'veil'. Different correspondents in the source text also has the Romanian word of Hungarian origin $a$ (se) (în)tîlni 'to meet', 'to cross', 'to overlap', which translates various Hungarian expressions, such as: összue ér 'to meet' (Ex., 28/27, 39/20) or leszec szömbe vele 'to cross' (Gen., 32/20). Another interesting case is that of the Romanian word of Hungarian origin aleaniş (see also aleaneş) 'enemy', 'opposer' which, in all its occurrences, corresponds to Hung. ellenség 'enemy'. As a matter of fact, the latter Hungarian word is, in turn, the etymon of another loanword in Romanian, i.e. alenşig 'enemy', recorded in another Romanian translation of Hungarian originals (in FRAG. TOD.). Although the bookish origin of aleaneş 'enemy' may not be excluded, what is remarkable is that translators have chosen this form over alenşig 'enemy', which has its etymon in the source text as correspondent to the former one.

3.2. Perhaps easier to deal with are those Hungarian loanwords which are savant neologisms belonging to the Hebrew terminology of the Bible and which translators could have borrowed, sometimes without any formal adaptation, directly from the Hungarian source. This is the case of words such as: pint 'measure for liquids'; sicluş 'old Hebrew coin' (in Po); amen 'Amen!' and joltar 'psalm' (in FRAG. TOD.), which appear as an immediate replica to the source text. The last two ones do not respond to a real necessity, since the Romanian language already possessed conventional terms for the notions they denote. Thus their presence might be explained either by the bilingual status of the translator, whose speech combines the two linguistic systems in such a manner in which he no longer considered necessary to replace the Hungarian words with their Romanian correspondents, or by the regional norm, in general, which had been strongly influenced by the Hungarian language accepting such forms. On the other hand, it is not excluded either that these loanwords reflect a certain acquaintance with Hungarian liturgical terminology, a habituation preserved, to a certain degree, in the seventeenth century as well.

3.3. The folk or elitist nature of one and the same Hungarian loanword may also vary according to the region referred to. In other words, the same lexical item may be considered of folk origin and usage in an area of direct contact between Romanians and Hungarians and gain strictly or mainly elitist usage in another area, where there were no contacts or, in any case, less vivid relations between the two nations. In the latter case, the term in question could not have been familiar to use and, thus, it has been retained in the Romanian translation due 
to other considerations than where it possibly belonged to the regional norm. For instance, it is interesting to see how the word alcam 'wickedness, trap' of Hungarian origin was recorded in the sixteenth century, in a region where it would be less motivated. It appears in two South-Transylvanian texts of Coresi, in $\mathrm{CP}$ and in $\mathrm{CC}_{2}(173 / 30)$, though the term was attested thereafter especially in North-Transylvania. Thus, its presence in the Coresian texts might have been due to the influence of some Northern originals.

In principle, the bookish origin of a Hungarian loanword encountered in a translation which had no Hungarian sources may be verified, to a certain degree, by collating the linguistic data available for the region where the text was written. For instance, the words recorded in Св or in Coresian texts, which have isolated occurrences, not found in any other texts belonging to the region of SouthTransylvania, most probably have a bookish origin. Although these elements might be explained by the influence of some Northern originals, it still represents a curiosity how and why these words have not been removed, or replaced by the author, typographer or reviewer of these texts. For instance, the word a otălmăzui 'to defend, to safeguard' retains our attention. It was recorded in MO and in $\mathrm{CC}_{1}$, where it might be due to some Hungarian originals, as it was suggested (Gheție \& Mareş 1985: 239, 267). Nevertheless, its preservation by the quite meticulous reviewer (Coresi) requires some further explanations, not entirely clarified yet. The word hition 'poor, miserable' raises more questions which was recorded in св (1Cor., 6, 2) in the sixteenth century. Its distribution includes NorthTransylvania and Moldova (Gafton 2001: 244), being less motivated thereof in the text mentioned above.

3.4. Hungarian loanwords of folk origin represent a much more complex situation than that of the elitist loanwords. These may be found not only in translations of Hungarian sources, but also in those Romanian translations which have had a Slavonic original. Compared to loanwords of bookish origin in which case the translation decision has been somewhat linguistically conditioned either by the source text or by the target system with certain shortcomings, in the case of those Hungarian loanwords which had been previously retrieved from a territorial variety of the spoken Hungarian language, the selection of this a priori material must have been governed by other factors. In this case, the translation decision might have been less constrained in the sense that translators could have granted themselves certain liberties in selecting what the most appropriate word was assumed to be, especially considering that for most of them there were Romanian correspondents to what these loanwords denote. In other words, the use of folk Hungarian loanwords may constitute not only a problem-solving decision, strictly speaking, as it has been for elitist loanwords, but also a technique or rather a strategy to accomplish a translation as felicitous as possible. 
3.4.1. Whether the translation was made from Hungarian or it had a Slavonic source, lexical units of the source language are substituted by corresponding units in the target language. Naturally, a descriptive study "should start from the empirical fact, i.e. from the translated text itself" (Hermans 1985: 13), but in assessing these equivalences we shall take into account the fact that the target text is not a mere reproduction of the source text. Given the systemic nature of translational phenomena, selection of words is governed by various principles. Thus the network of textual relations present in the source text tends to be transformed or ignored in translation, being substituted by habitual target repertoire options (Toury 1995: 268). This might be observed in cases in which the Romanian translation does not apply the correspondent of Hungarian origin, although its etymon is found in the source text. In this case, the choice is made in favour of another correspondent in use which is of Latin or Slavonic origin. But there are also cases in which the translator alternatively uses different synonyms of the same word, among these being those of Hungarian origin too. Thus, Hungarian loanwords enter various synonymic series within the same translation. For instance, Hungarian loanwords in Cv are alternatively used with their synonyms to denote the same extralinguistic reality, forming series such as: chin - muncă - pănătare 'torment, pain'; chip - obraz 'face'; feleleat - răspuns cuvînt 'answer'; gînd - cuget 'thought'; hicleşug - sfadă - ferecare - întorcătură 'cunningness'; a lăcui - a prebîndi 'to reside, to live'; a (se) mîntui - a (se) spăsi - a izbăvi 'to redeem'; a ponoslui - a ocări - a defăima - a oblici - a cleveti 'to reproach, to insult'; neam - sămînță 'nation, ancestry'; tar - sarcină 'load'; $\boldsymbol{a}$ tăgădui - a lepăda 'to deny'; vamă - preț - mită 'customs' etc. where the forms in bold are folk Hungarian loanwords. Similarly, in cs Hungarian loanwords appear as synonyms to Romanian words inherited from Latin or borrowed from Slavonic: alămojnă - pomeană 'alms, pittance'; beteag - nevolnic 'weakling'; bratăş - soț 'companion, fellow'; hiclean - diavol - drac 'devil'; fel - rînd 'kind (of)'; hasnă - folos 'utility'; a îngădui - a ogodi 'to allow'; marh ă - avuție 'wealth'; samă număr 'number'; orass - cetate 'city' etc. In PO we could mention series such as: bărătaş - priiatnic 'friend'; beseadă - cuvînt - glas - grai - limbă 'discourse, word, language'; biruiți - domniți 'to reign'; buduşlău - nestătoriu 'wanderer'; ciurdă - turmă 'herd'; a sălăşui - a răposa - a odihni 'to repose' etc. ${ }^{4}$

As mentioned before, these Hungarian loanwords function as equivalences to the lexical items found in the source text either Hungarian or Slavonic. At this point, it is interesting to see what the factors were which determined or influenced, in a way or another, the selection of these equivalences over others

4 The given examples are only illustrative. The number of these synonymic series would increase if we selected each and every Hungarian loanword within a translation and gave their synonyms, on the one hand, and if we regarded them in the larger context of old Romanian language, comparing the translations and also other writings of the epoch among them, on the other hand. 
possible within the system of the target language. It is known that in a peripheral, less prestigious position within the system, translation will tend to replicate existing models while in a central, prestigious position, translation will be allowed to bring innovation into the system. In this regard, we may observe the fact that, in some cases, the Hungarian loanword appears in the translation as counterpart of an older synonym, which seems to have lost its position within the system, at least in frequency, being concurred, competed and, ultimately, replaced precisely by the former one. This is the case of the Romanian word of Hungarian origin $a$ (se) mîntui 'to redeem' which, eventually, replaced in modern Romanian language its older synonym of Slavonic origin a (se) spăsi 'to redeem', still in use, but weakened in the sixteenth century. It is also interesting that the Hungarian loanword, in turn, has been rivalled by Sl. a izbăvi 'to redeem' in later stages of the Romanian language evolution. In other cases, the Hungarian loanwords function as regional synonyms for older Romanian terms. For instance, beseadă 'discourse, word', a buduşlui 'to wander', feleleat 'answer', hasnă 'utility', marhă 'wealth', samă 'number', tar 'load' are loanwords characteristic of the region of Banat-Hunedoara, where these probably corresponded to the regular use and norm of the local dialects. Hence, in this equivalence situation, Hungarian loanwords have been employed in the target language material "not because they are important in any inherent sense, but because they are assigned importance, from the recipient vantage point” (Toury 1995: 12).

3.4.2. Naturally, the selection of a Hungarian loanword is not always up to the translator's free choice. There are cases in which these lexical items have been introduced in the target text as a consequence of the translator's applying "techniques of adjustment" (Nida 1964), whose aim has been to produce correct equivalents, adjusting the message to the structural requirements of the target language, producing semantically equivalent structures and providing stylistically appropriate equivalents. Rarely, in translations of Slavonic originals, the choice for a particular Hungarian loanword has been determined by the translators' attempts to render a meaning of the source text as precise and faithful as possible, while the Hungarian term adopted has been probably of bookish origin, previously acquired from Hungarian sources or from other Romanian translations consulted. This might explain, for instance, the use of the Hungarian verb a pesti 'to linger' in Св (FA, 20, 16), selected in order to render the meaning assumed by the translator (Gafton 2001: 246). As a matter of fact, the term was recorded in two other translations as well, in CV, whose original is supposed to belong to Banat-Hunedoara, and in CP, a South-Transylvanian text. In all the three texts, the Hungarian loanword appears in the same passage to render the same meaning. ${ }^{5}$

$5 \quad$ See also its derivatives: pesteală 'delay' (св, FA, 25, 17) and pestit 'slow' (св, FA, 27, 7). 
3.4.3. A completely different situation may be observed in the case of those Hungarian loanwords used in Romanian translations of Slavonic originals, which are preferred even to their Romanian synonyms of Slavonic origin. Such a preference may be observed in св, where sometimes, apparently unmotivated, Hungarian loanwords are selected for a certain notion to be translated with instead of a Slavonic one (Gafton 2001: 242-243). Moreover, this choice is made even in situations in which other translation versions included, in the same passage, a term of Slavonic origin. For instance, the Romanian word of Hungarian origin celuitor 'deceptive' is preferred in св (Sp. la 2Ioan) to its synonyms of other origin prilăstitori 'alluring' and înşelătoriu 'deceitful' (2Ioan, 1, 7) recorded in CP. Similarly, the verb a făgădui 'to promise' seems to represent a free option of the cв’s translator since, in the sixteenth century, it had its synonyms: a giurui 'to swear' (cv) and a jura 'to swear' (СР), recorded in the other versions of the biblical text.

As a matter of fact, a certain degree of propensity with respect to Hungarian loanwords may be observed in the seventeenth century as well, particularly in religious texts. This kind of deliberate disposition to Hungarian loanwords, especially in passages where other versions of the same text prefer other terms, may be traced, for instance, in Nтв (Gafton 2005: 146). Thus, the Romanian word of Hungarian origin oraş 'city' is almost generally used in NTB, whereas its synonym of Latin origin cetate 'city' prevails in св, СР and вв; similarly, chipurele 'faces', which is of Hungarian origin, is preferred in NTB (FA, 7, 43) to obrazele 'faces' (св, СР) which is a word of Slavonic origin; tîrnaț 'porch' (NTB, FA, 3, 11) of Hungarian origin is preferred to tindă 'porch' (in СB, СР) of Latin origin; and the word of Hungarian origin viteaz 'valiant' prevails in NTB (FA, 10, 7) over voinic 'brave' (in $\mathrm{CB}, \mathrm{CP}$ ) of Slavonic origin. Besides these, NTB records other Hungarian loanwords too, such as: beseadă 'discourse'; a cebălui ‘to stun, to (be) bewilder(ed)'; a murgui 'to reprove, to trouble, to tease'. Most probably, some of the Hungarian loanwords have been perceived by translators as part of the "cult norm" in BB as well (Gafton 2005: 137). In this regard, we shall give only one example, that of the Romanian verb of Hungarian origin a birui 'to command, to govern, to dominate', which also has different derivatives, such as those written in bold in the following contexts: biruitoriu şi judecătoriu 'conqueror and judge' (вв), chosen over jude 'judge' (св, $\mathrm{CP}$ ) or domnu 'lord' (NTB); biruința limbilor 'reign over languages (or peoples)' (вв) as opposed to ținearea limbilor 'holding of languages (or peoples)' (NTB); or întru a ta biruință 'in your command' (вв) instead of în putearea ta 'in your power' (NTв).

3.4.4. Sometimes the motivation which stays behind the use of a Hungarian loanword in a certain segment of the target text seems to exceed the translation task itself. In other words, some of the lexical items do not correspond to a meaning found in the source text, but they appear as fillings, not entirely unjustified though. They seem not to satisfy an actual translation need, but rather other Skopos. Old 
Romanian translators seem to assume roles other than that of a translator, strictly speaking. While in the case of the segment: Nestătoriu şi buduşlău 'Restless and wanderer' (Po, Gen., 4/12), the use of the Hungarian loanword written in bold does correspond to a translation task since the source text imposes the presence of both terms (cf. Nyughatatlan es Budoso 'Restless and wanderer') and, furthermore, there is a slight difference in nuance between the two synonyms; the presence of a Hungarian loanword in the context of its partial synonym is not always imposed by the source text, neither by linguistic requirements of the target language. For instance, the use of hasnă 'utility' ( $<$ Hung. haszna), although in Romanian there existed folos 'utility', and especially in the context of the latter one-see in: Folosuri şi hasne 'Utilities and utilities' (Po, Preface) - seems to have its explanation beyond the requirements of the Romanian language system since neither of these synonyms has specialized its meaning, nor have they semantically overloaded (Gafton 2010: 79). Nevertheless, the use of the Hungarian loanword is not superfluous nor parasitic, not even in the context above (somewhat independent of a source text), since, at that time, the term in discussion was in use in the spoken local dialect, perceived, probably, as according to the regional norm. Thus, Romanian translators might have intended here to enrich a certain synonymic series, endowing Romanian language with a means of expression appropriate to religious content. An argument of this claim might be the fact that the Hungarian loanword follows its Romanian synonym, as an addition to it. There are other examples too, in which a Hungarian loanword is included in the same context as its Romanian counterpart, being used as synonyms in the given passage. This is the case of samă 'number', in: Sama şi numărul 'Number and number' (PO, Preface); of sălaş 'shelter', in: Numărul sălaşelor şi locurelor 'Number of shelters and of shelters (places)' (po, Preface); or of aleaneş 'adversary', in: protivitoriu va fi aleaneşului tău 'adversary shall be to its adversaries' (PO, Ex., 23, 22). ${ }^{6}$ In these contexts, there are multiple explanations for the use of the Hungarian loanwords. On the one hand, they may reflect the current use of the regional norm and, as such, they are common and natural elements either in the creative process of elaborating a message, in the first two examples, or in the course of a translation task, in the latter example. On the other hand, it is not excluded that translators were aware of the regional character of these Hungarian loanwords and, as a consequence, they intended to clarify their meaning, repeating it by their Romanian synonyms. This explanation by the Romanian synonyms following the Hungarian loanwords might have been necessary, since translators' intention

6 The structure is, in fact, a calque of a Hungarian expression. It is interesting, however, that while the Hungarian source repeats the same word (cf. ellensege leszec a te ellensegednec 'I shall be enemy to your enemy'), the Romanian translator chooses to apply two different synonymic lexemes (protivitoriu 'enemy, adversary' and aleaneş 'enemy'). This fact may show a tendency to refine the utterance. 
had been to address to all Romanians, including those who did not belong to the region of Banat-Hunedoara and, thus, for whom these loanwords might have been unknown. As a matter of fact, this need for an additional explanation may be found in the case of the word băsău 'revenge' too, included in the passage: Sta-voiu băsău sau în alean 'I shall take revenge or (be) against' (Po, Gen. 9, 5). In this passage, the Hungarian loanword appears, in fact, as a result of a Hungarian calque (cf. boszszut álloc 'I shall take revenge') and, therefore, it probably required certain clarification. It is interesting, however, that this clarification is made by the use of another Hungarian loanword (în alean '(be) against, adversary'), which shows that this latter word had been previously acquired occupying a stronger position in the system being more common than the former one. Additionally, it is not excluded either that by these Hungarian loanwords translators could have intended to refine and nuance the means of expression in Romanian, since they might have felt their native language to be less developed in this respect, at least compared to the source languages.

4. Overall, Hungarian loanwords function both as strategy, i.e. a planned, explicit, goal-oriented procedure, adopted to achieve a certain objective, and as tactics or (sequence of) steps, locally implemented. ${ }^{7}$ As a strategy, they stand for the whole translation event including what is happening before and after the translation itself, while as tactics they play a role in the translation act. Sometimes Hungarian loanwords are used as "procedures" (Newmark 1988), applied to smaller units of language, whereas in other cases they may be regarded as "methods" based on the whole text. For instance, in Po, Hungarian source language structures are, occasionally, so conspicuously imitated in the target text as if "the Romanian translator needed to show someone that a Hungarian source has been used" (Arvinte \& Gafton 2007: 87).

The translator may manipulate the linguistic material in order to produce an appropriate target text segment. Some of these strategies are globally implemented, others are of local impact, both contributing to comprehension or production (see also Chesterman 1997: 92). Hungarian loanwords of bookish origin usually appear as a result of controlled, conscious processes employed to solve local problems. In case of folk Hungarian loanwords there is yet another possibility. Sometimes the selection of these lexical items could have been an uncontrolled or automated process since it is quite hard to tell what is going on in the "black box" of the translator. Being a bilingual speaker and an exponent of a certain regional dialect, he might not always have taken into account attentively which Hungarian loanwords would not be understood by speakers of another dialect, whether monolinguals or not. Hence, there could have been situations in which a loanword of Hungarian origin recorded in the target text was presumably less consciously included, i.e.

$7 \quad$ For terminological explanations of strategy, technique, tactic etc. see also Yves Gambier. 
translators being less aware of the possible reactions of the reader. On the other hand, a feature given in the source text segment might not represent a difficulty to the translator, but the chosen solution might become problematic for the reader (see Lörscher 1991). As mentioned before, the translators belonged mostly to a region strongly influenced by Hungarian, which may explain the considerable number of Hungarian loanwords in these Romanian translations. Among them there were many loanwords which were familiar in other regions less influenced by Hungarian too. But, definitely, there were terms which were unknown not only for readers from other linguistic areas, but also for the ones belonging to the same region. This is the case of many calques of Hungarian structures too. Some of them were probably understood without any particular problem by readers of BanatHunedoara who had been acquainted with the Hungarian way of expression and, thus, even if they encountered an unknown word in a passage, they could unravel the meaning of the given passage. For readers of other areas, on the contrary, a difficulty might have posed not only a given lexical item but also the unusual association or order of certain lexemes, whether familiar or not.

Naturally, translation decisions are the final outcome of a rational activity, based upon consideration of risks, benefits, alternatives, comparisons, previous solutions from earlier translations, etc. Hence, in overall, Hungarian loanwords have been selected with great care, especially due to the religious content of the translations. Thus, translators had to ensure the readers about the credibility of the text, on the one hand, and to provide them intelligibility, on the other hand, which also presumed to discard, as far as possible, of all unnecessary or regional elements since God's words had to be conveyed to everyone, regardless of their territorial affiliation.

The selection of Hungarian loanwords corresponds to both initial, i.e. of semiotic priority and operational translational norms (see Toury 1995: 54-55). In the first case, translators favoured the choice for a certain Hungarian loanword in order to accomplish either adequacy, i.e. adherence to source culture norms, since the Hungarian Bible translation and language were given high regard, or acceptability, i.e. a preference for the norms of the target culture whenever the need to intelligibility prevailed.

Undoubtedly, there existed textual-linguistic norms too, which governed the choice of target textual-linguistic material to replace the one found in the source text. Some of the target language solutions provided by the translators are retrieved through automatic or routine processes, given their bilingual status. The frequent use of certain solutions can become routine, although a boundary between routine and non-routine translation strategy and solution is sometimes difficult to draw. The translators' actions lie between unconscious, preconscious or potentially conscious and conscious strategies, according to their situation. For instance, the choice to name the first two books of the Bible translation PO as 
Bitia 'Genesis' and Ishod 'Exodus', which follow the Slavonic tradition, despite the fact that the Romanian translation did not have a Slavonic but Latin and Hungarian sources, shows the translators' intention to justify and legitimate the target text since, in that time, Slavonic was the acknowledged church language.

In the majority of the cases, the choice for Hungarian loanwords as literal and / or free translation, formal and / or dynamic equivalences is goal-oriented, focused on facilitating the translation task (see Lörscher 2002). Hungarian loanwords in this perspective function as problem-solving techniques, aiming at particular choices about specific points of the translated text. As such, their use is due to constraints either of the source text, in which case they appear as a response to a need for adequacy, or of the target language system, where they are needed in order to fill certain lacunas. Less commonly, the use of a given Hungarian loanword appears as a preference for a model, i.e. Hungarian, which has been considered superior in one respect or another. Finally, Hungarian loanwords, though rarely, seem to reflect a strategic decision, whose aim exceeds the translation per se.

\section{References}

\section{Text editions}

$\mathrm{Bв}=$ Biblia 1688 [Bible 1688], edited by V. Arvinte, I. Caproşu, Al. Gafton, Laura Manea, N. A. Ursu, 2. vol., Iaşi, 2001, 2002.

$\mathrm{CB}=$ Codicele Bratul [Codex of Brat], edited by Alexandru Gafton, Iaşi: Alexandru Ioan Cuza University Press, 2003.

$\mathrm{CC}_{1}=$ Coresi, Cazania I, cca 1567 [1st Homiliary, aprox. 1567], edited by Vladimir

Drimba, Bucureşti: Romanian Academy Press, 1998. $\mathrm{CC}_{2}=$ Coresi, Cazania a II-a, Braşov, 1581 [2nd Homiliary, Braşov, aprox. 1581], edited by Sextil Puşcariu \& Alexe Procopovici, Bucureşti, 1914. $\mathrm{CP}=$ Texte de limbă din secolul XVI [Texts of (Romanian) language from the sixteenth century], reproduced in facsimile, edited by I. Bianu, Romanian Academy member, IV. Lucrul Apostolesc. Apostolul tipărit de diaconul Coresi la Braşov în anul 1563 [IV. The Apostolic Act. The Apostle printed by Coresi in 1563 at Braşov], Bucureşti, 1930.

Cs = Codex Sturdzanus [Codex Sturdzanus], philologic and linguistic study, text edition and glossary of words by Gh. Chivu, Bucureşti, 1993.

$\mathrm{cv}=$ Codicele Voronețean [Codex from Voroneț], critical edition, philologic and linguistic study by Mariana Costinescu, Bucureşti: Minerva Press, 1981.

FRAG. TOD. = Fragmentul Todorescu [Fragment of Todorescu], philologic and linguistic study, text edition and glossary of words by Ion Gheție. In: Texte româneşti din secolul al XVI-lea. I. Catehismul lui Coresi. II. Pravila lui Coresi. 
III. Fragmentul Todorescu. IV. Glosele Bogdan. V. Prefețe şi epiloguri [Romanian texts of the sixteenth century. I. Catechism of Coresi. II. Laws of Coresi. III. Fragment of Todorescu $=$ The Book of Psalms. IV. Glosses of Bogdan. V. Prefaces and Epilogues], Gheție, Ion (coord.), Bucureşti: Academy Press, 1982. 259-364. мо = Coresi, Molitvenic rumânesc, cca 1567 [Romanian Prayer Book, aprox.

1567], edited by Vladimir Drimba, Bucureşti: Romanian Academy Press, 1998. NTB = Noul Testament $[$ The New Testament], first printed in Romanian in 1648

by Simion Ştefan, Bishop of Transylvania, reedited after 350 years with the blessing of His Grace Andrei, archbishop of Alba Iulia, Alba Iulia, 1998. PO = Palia de la Orăştie (1582), I., Textul [The Old Testament from Orăştie (1582),

I., The Text], text edition by Vasile Arvinte, Ioan Caproşu and Alexandru Gafton, Iaşi: Alexandru Ioan Cuza University Press, 2005.

Po 1925 = Palia d'Orăştie 1581-1582, I (...), Préface et Livre de la Genèse publiés avec le texte hungrois de Heltai et une introduction par Mario Roques [The Old Testament from Orăştie 1581-1582, I (...), Preface and the Book of Genesis published by Mario Roques, accompanied by the Hungarian text of Heltai and by an introduction], Paris, 1925.

\section{References}

Arvinte, Vasile \& Alexandru Gafton. 2007. Palia de la Orăştie (1582). II. Studii [The Old Testament from Orăştie (1582). II. Studies]. Iaşi: Alexandru Ioan Cuza University Press.

Chesterman, Andrew. 1997. Memes of Translation: The Spread of Ideas in Translation Theory. John Benjamins Publishing.

Drăganu, Nicolae. 1921-1922. Din cel mai vechiu molitvenic românesc [From the Oldest Romanian Prayer Book]. Dacoromania, II: 253-326.

Gafton, Alexandru. 2001. Evoluția limbii române prin traduceri biblice din secolul al XVI-lea [Romanian Language Evolution through Biblical Translations from the $16^{\text {th }}$ century]. Iaşi: Alexandru Ioan Cuza University Press.

Gafton, Alexandru. 2005. După Luther. Traducerea vechilor texte biblice [After Luther. Translation of Old Biblical Texts]. Iaşi: Alexandru Ioan Cuza University Press.

Gafton, Alexandru. 2009. Relația dintre sursele traducerilor biblice şi concepția de la baza acestora [The Relationship between the Sources of Biblical Translations and their Basic Translation Theory]. In: Gafton, Alexandru; Guia, Sorin \& Milică, Ioan (eds.), Text şi discurs religios [Religious Text and Discourse], 125134. Iaşi: Alexandru Ioan Cuza University Press.

http://media.lit.uaic.ro/gafton/relatiacusursele.tdr1.pdf (25 July, 2012).

Gafton, Alexandru. 2010. Consecințele profunde ale contactelor lingvistice [The Profound Consequences of Linguistic Contacts]. In Chivu Gh., Oana Uță- 
Bărbulescu (eds.), Studii de limbă română. Omagiu profesorului Grigore Brâncuş [Romanian Language Studies. Festschrift for Professor Grigore Brâncuş], 77-100. Bucureşti University Press.

Gafton, Alexandru. 2011a. Asupra unei traduceri din Noul Testament de la Bălgrad (1648) [About a translation from The New Testament of Bălgrad (1648)]. In Gafton, Alexandru; Guia, Sorin \& Milică, Ioan (eds.), Text şi discurs religios [Religious Text and Discourse], 205-207. Iaşi: Alexandru Ioan Cuza University Press. http://www.cntdr.ro/sites/default/files/c2010/ c2010a20.pdf (25 July, 2012).

Gafton, Alexandru. 2011b. Particularități ale traducerii în Biblia de la Bucureşti şi în Noul Testament de la Bălgrad. Cu ilustrări din Epistola lui Iacov [Translation Peculiarities in the Bible of Bucharest and in The New Testament of Bălgrad. With Examples from St. James' Epistles]. Limba română [Romanian Language], LX(2): 261-272, http://media.lit.uaic.ro/gafton/Gafton.LR.Ursu.pdf (25 July, 2012).

Gheție, Ion, ed. 1982. Cele mai vechi texte româneşti. Contribuții filologice şi lingvistice [The Oldest Romanian Texts. Philologic and Linguistic Contributions]. Bucureşti: University Press.

Gheție, Ion \& Alexandru Mareș. 1985. Originile scrisului în limba română [The Origins of Writing in Romanian Language]. Bucureşti: Scientific and Encyclopedic Press.

Hermans, Theo (ed.). 1985. The Manipulation of Literature. Studies in Literary Translation. London/Sydney: Croom Helm.

Lambert, José \& Hendrik van Gorp. 1985. On Describing Translations. In Hermans, Theo (ed.), The Manipulation of Literature, 42-53. London and Sydney: Croom Helm.

Lörscher, Wolfgang. 1991. Translation Performance, Translation Process and Translation Strategies. A Psycholinguistic Investigation. Tübingen: Narr.

Lörscher, Wolfgang. 2002. A model for the analysis of translation processes within a framework of systemic linguistic. Cadernos de Tradução 10 (2): 97-112. http://www.periodicos.ufsc.br/index.php/traducao/article/view/6146/5704 (13 April, 2010).

Newmark, Peter. 1988 (1995). A Textbook of Translation. London: Prentice Hall. Nida, Eugen. 1964. Toward a Science of Translating. Leiden: Brill.

Rosetti, Al. 1931. Limba română în secolul al XVI-lea [Romanian Language in the $16^{\text {th }}$ century]. Bucureşti: Romanian Book Press.

Toury, Gideon. 1995. Descriptive Translation Studies and Beyond. Amsterdam and Philadelphia: John Benjamins.

Yves Gambier: Translation Strategies and Tactics. https://www.benjamins.com/ online/hts/ (4 March 2014). 